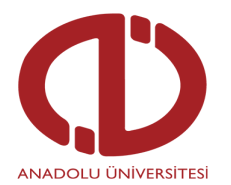

Açıköğretim Uygulamaları ve Araştırmaları Dergisi AUAd

https://dergipark.org.tr/tr/pub/auad

Gönderim: 05.10 .2021

Düzeltme: 18.12 .2021

Kabul: 31.01 .2022

Tür: Araştırma Makalesi

\title{
Ortaokul öğrencilerinin bilişim teknolojileri öz-yeterlik algıları ile bilişim teknolojileri ve yazılım dersine yönelik görüsslerinin belirlenmesi
}

\section{Özge ÖZTUZCU}

Ayşen KARAMETE ${ }^{b}$

a Balıkesir Üniversitesi, Fen Bilimleri Enstitüsü, Bilgisayar ve Öğretim Teknolojileri Anabilim Dalı, ORCID: 0000-0003-2836073X

b Balıkesir Üniversitesi, Necatibey Eğitim Fakültesi, Bilgisayar ve Öğretim Teknolojileri Eğitimi Bölümü, ORCID: 0000-

0001-8442-2080

\begin{abstract}
Özet
Günümüz çocukları teknoloji ile çok küçük yaşlarda tanışmaya başlamış olmalarına rağmen teknoloji kullanımları günlük kullanım becerileri ile sınırlı kalmaktadır. Türkiye'de 2013 yılından itibaren beşinci ve altıncı sınıflarda zorunlu, yedinci ve sekizinci sınıflarda ise seçmeli olarak Bilişim Teknolojileri ve Yazılım (BTY) dersi verilmektedir. Bu çalışmanın amacı ortaokul öğrencilerinin BTY dersine ilişkin öz-yeterliklerini ve görüşlerini belirlemektir. Araştırmanın çalışma grubunu 2020-2021 eğitim öğretim yılında Balıkesir ilinde yer alan okullarda öğrenimine devam eden 200 öğrenci oluşturmaktadır. Araştırma karma araştırma deseni ile tasarlanmıştır. Araştırma sonucunda öğrencilerin BTY dersine ilişkin öz-yeterliklerinin orta düzeyde olduğu, baba eğitim düzeyi ve kendine ait bilgisayara sahip olma değişkenlerine göre anlamlı bir farklılık gösterdiği sonuçlarına ulaşılırken cinsiyet, sınıf düzeyi, anne eğitim düzeyi ve internet erişim değişkenlerine göre anlamlı bir farklılık göstermediği sonuçlarına ulaşılmıştır. Öğrencilerin BTY dersine ilişsin görüşlerinin olumlu yönde olduğu sonucuna ulaşılmıştır.
\end{abstract}

Anahtar Sözcükler: Bilişim teknolojileri ve yazılım, ortaokul öğrencileri, öz-yeterlik, görüş, Covid-19.

\section{Determination of middle school students' perceptions of information technology self-efficacy and their opinions about information technology and software courses}

\begin{abstract}
Even though today's youngsters have been exposed to technology since they were very young, their usage of technology is limited to their everyday skills. Since 2013, Information Technology and Software (ITS) courses have been taught in Turkey in the fifth and sixth grades as compulsory courses and in the seventh and eighth grades as elective courses. The research aims to examine secondary school students' self-efficacy and opinions on the ITS course. The research's working group consists of 200 students who continue their education at Balıkesir province schools in the 2020-2021 academic year. The study used a mixed research design. As a result of this research, it was found that students' self-efficacy for the ITS course was moderate, with a substantial variation depending on father's educational level, and own computer ownership. The students' opinions regarding the BTY course were found to be positive.
\end{abstract}

Keywords: Information technologies and software, middle school students, self-efficacy, opinion, Covid-19.

Öztuzcu, Ö. ve Karamete, A. (2022). Ortaokul öğrencilerinin bilişim teknolojileri öz-yeterlik algıları ile bilişim teknolojileri ve yazılım dersine yönelik görüşlerinin belirlenmesi. Açıköğretim Uygulamalart ve Araştırmaları Dergisi (AUAd), 8(1), 64-86. 


\section{Giriş}

Günümüzde çocuklar, teknoloji ile çok küçük yaşlarda tanışmaktadır ve teknoloji kullanımının arttığı evlerde büyümektedirler. Bilişim Teknolojileri [BT] hayatımızın vazgeçilmez bir parçası haline gelmiştir. BT kavramı ilk olarak 1960'lı yıllarda ortaya çıkmıştır ve BT’nin yaygınlaşması ile gelişmeye devam etmiştir. BT bilginin toplanmasını, işlenmesini, depolanmasını sağlayan teknolojiler iken öz-yeterlik ise bireyin bir işi yapmak için gereken becerileri gerçekleştirme konusunda kendine olan inancıdır (Bandura, 1997; Zimmerman, 1995). Öz-yeterlik inancı yüksek olan bireyler her zaman başarıya odaklıdırlar (İnanç ve Yerlikaya, 2011) ve öğrencilerin; dosya uzantılarını bilmesi, sunu hazırlama ve düzenleme programlarında bir konu hakkında sunu hazırlayabilmesi, bilgisayarın iç donanım ve diş donanım parçalarını sıralayabilmesi, bulut depolama araçlarını kullanabilmesi Bilişim Teknolojileri ve Yazılım [BTY] öz-yeterlikleri arasında yer almaktadır. Alanyazında yapılmış olan çalışmalar incelendiğinde ortaokul öğrencilerinin BTY dersine ilişkin öz-yeterlikleri ve BTY dersine yönelik görüşlerini inceleyen herhangi bir çalışmaya rastlanmamıştır. Öğrencilerinin BTY dersine ilişkin öz-yeterliklerinin ve BTY dersi ile ilgili görüşlerinin birlikte ele alınmasının alana katkı sağlayacağına inanılmaktadır.

\section{Araştırma Sorunsalı}

Çocuklar eğitim hayatlarına başlamadan birçok teknolojik ürünü kullanabilirler ancak bu durum teknolojiyi günlük hayatta kullanma becerileri ile sınırlı kalmaktadır. Teknolojinin hayatımızda yoğun bir şekilde yer alması teknoloji eğitimini hayatımızda zorunlu hale getirmiştir (EDUCAUSE, 2021). Bu nedenle Türkiye'de 5. sinıftan itibaren zorunlu olarak BTY dersi verilmeye başlanmıştır (Göçer ve Türkoğlu, 2018). Milli Eğitim Bakanlığı [MEB](2019) tarafından hazırlanan program içerisinde yer alan kazanımlar, öğrencilerin teknolojinin sosyal hayatla olan ilişkisine yönelik farkındalıklarını artırma ve teknolojinin teknik boyutlarına yönelik becerilerini geliştirme konusunda güçlü bir içerik oluşturulmasını sağlamıştır. BTY dersinde "Bilişim Teknolojileri”, "İletişim, Araştırma ve İşbirliği”, "Etik ve Güvenlik”, "Problem Çözme ve Programlama" ve "Dijital Ürün Oluşturma" üniteleri yer almaktadır. Talim ve Terbiye Kurulu tarafından onaylanan programda yer alan kazanımlarına göre öğrenciler ilk dönemde BT kavramlarını öğrenecekler ve önemli sosyal konularda farkındalıklarını artıracaklardır. İkinci dönemde ise programlama becerileri başta olmak üzere kazandırılacak teknik beceriler, onları, teknolojiyi tüketen değil, teknoloji üreten bir konuma getirmeyi hedeflemektedir (MEB, 2019). $\mathrm{Bu}$ araştırma, ortaokul öğrencilerinin Covid-19 sürecinde yaşadıkları olumlu/olumsuz durumlara yönelik görüşlerinin alınması açısından güncel; ortaokul öğrencilerin BTY dersine ilişkin öz- 
yeterlikleri ile BTY dersine yönelik görüşlerini ele alan herhangi bir çalışma bulunmaması açısından özgün; BTY dersinde zorlanılan konuların öğrenilmesinin BY öğretmenlerinin farkındalık kazanmaları ve bu konularda materyal tasarlayacak olan araştırmacılar için konu tespiti yapılması yönlerinden gerekli olarak görülmektedir. Buradan hareket ile bu araştırmanın amacı ortaokul öğrencilerinin BTY dersine ilişkin öz-yeterliklerini ve BTY dersine yönelik görüşlerini belirlemektir. Bu amaca ulaşabilmek için aşağıdaki sorulara cevap aranmıştır:

- Öğrencilerin BTY dersine ilişkin öz-yeterlikleri ne düzeydedir?

○ Öğrencilerin BTY dersine ilişkin öz-yeterlikleri cinsiyete göre farklılaşmakta midir?

○ Öğrencilerin BTY dersine ilişkin öz-yeterlikleri sınıf düzeyine göre farklılaşmakta midir?

○ Öğrencilerin BTY dersine ilişkin öz-yeterlikleri anne eğitim düzeyine göre farklılaşmakta mıdır?

○ Öğrencilerin BTY dersine ilişkin öz-yeterlikleri baba eğitim düzeyine göre farklılaşmakta mıdır?

○ Öğrencilerin BTY dersine ilişkin öz-yeterlikleri bilgisayara sahip olma durumlarına göre farklılaşmakta mıdır?

○ Öğrencilerin BTY dersine ilişkin öz-yeterlikleri internet erişim durumlarına göre farklılaşmakta mıdır?

- Öğrencilerin BTY dersine yönelik görüşleri nelerdir?

- Öğrencilerin Covid-19 pandemisi sürecinde yaşadıkları olumlu ve olumsuz durumlar nelerdir?

\section{İlgili Alanyazın}

BT’nin hayatımızda yer alması ve BTY dersinin zorunlu olarak verilmeye başlaması ile BTY dersi ile ilgili araştırmalar yapılmaya başlanmıştır. Yapılan alanyazın taraması sonucunda öğrencilerin; bilgisayar kullanım öz-yeterliklerinin, BTY dersinde öğrendikleri bilgileri diğer derslere göre kullanma becerilerinin, BTY dersine yönelik kavram yanılgılarının ve görüşlerinin incelendiği çalışmalara rastlanılmıştır. Aynı zamanda alanyazında öğrencilerin; BTY dersi ile akademik başarıları arasındaki ilişkiyi, internet bağımlılıklarını ve öğrencilerin BT'den yararlanma seviyelerini inceleyen çeşitli çalışmalar da bulunmaktadır. 


\section{Çalışmayla Doğrudan İlişkili Araştırmalar}

Vekiri ve Chronaki (2008) yapmış oldukları çalışmada öğrencilerin okul dışı bilgisayar deneyimleri, bilgisayar öğrenmeye yönelik öz-yeterlikleri ve değer inançları arasındaki ilişkileri incelemişlerdir ve araştırma sonucunda tüm öğrencilerin okul dışında bilgisayar kullanıyor olmalarına rağmen, bilgisayar kullanım sıklıkları açısından cinsiyetler arasında farklılıklar olduğu bulgusuna ulaşmışlardır. Solmaz (2015) yapmış olduğu çalışmada öğrencilerin BTY dersinde öğrendiklerini diğer derslerde kullanma becerilerini incelemiştir ve kız öğrencilerin BTY ders yeterliklerinin erkek öğrencilerden yüksek olduğu sonucuna ulaşmıştır. Usta ve diğerleri (2016) yapmış oldukları çalışmada ortaokul öğrencilerinin BTY dersi kapsamındaki kavram yanılgılarını belirlemeyi amaçlamışlardır ve araştırma sonucunda ortaokul öğrencilerinin BTY dersi kapsamındaki kavramlara dair eksik öğrenmelerinin olduğuna ve kavram yanılgılarına sahip olduklarına ulaşmışlardır. Göksoy ve Yılmaz (2018) robotik kodlama dersi alan öğrencilerin ve dersi veren BT öğretmenlerinin robotik kodlama dersi hakkındaki görüşlerini belirlemeyi amaçlamışlardır ve araştırma sonucunda BT öğretmenlerinin ve ortaokul öğrencilerinin, robotik ve kodlama dersinin öğrencilere problem çözme, yaratıcı düşünme gibi kazanımlar sağladığı ve öğrencilerin sayısal derslerde akademik başarılarının arttığı görüşünde olduklarına ulaşmışlardır. Alanyazında öğrencilerin BTY dersi ile akademik başarıları arasındaki ilişkiyi inceleyen çalışmalar bulunmaktadır (Özgenel ve diğerleri, 2018; Özkan ve Şahin, 2019). Özgenel ve diğerleri (2018) öğrencilerin BTY dersine yönelik tutumları ile akademik başarıları arasındaki ilişkiyi incelemeyi amaçlarken Özkan ve Şahin (2019) BT dersine yönelik öğrenme stratejilerini ve kullanım sıklıklarını farklı değişkenler açısından incelemeyi ve inceleme sonucunda öğrenim stratejilerinin öğrencilerin akademik başarıları ile ilişkisini belirlemeyi amaçlamışlardır. Yapılan çalışmalar sonucunda öğrencilerin BTY dersine yönelik tutumları ve öğrenim stratejileri arasında pozitif yönde ilişki olduğu sonucuna ulaşmışlardır. Alanyazında öğrencilerin internet bağımlılıklarını inceleyen çalışmalar bulunmaktadır (Ulaş-Karaahmetoğlu, 2020; Eryılmaz ve diğerleri, 2020). UlaşKaraahmetoğlu (2020) yapmış olduğu çalışmada öğrencilerin bilgisayar kullanımları ile internet bağımlılıklarının düzeylerini belirlemeyi amaçlarken Eryılmaz ve diğerleri (2020) yapmış oldukları çalışmada öğrencilerin BT öz-yeterlik algıları ve internet bağımlılıkları arasındaki ilişkiyi farklı demografik özelliklere göre incelemeyi amaçlamışlardır. Yapılan çalışmalar sonucunda Ulaş-Karaahmetoğlu (2020) öğrencilerin bilgisayar kullanımları ve internet bağımlılıklarının farklı değişkenlere göre değiştiği sonucuna ulaşırken Eryılmaz ve diğerleri (2020) öğrencilerin BT öz-yeterlikleri ile internet bağımlılıkları arasında orta düzeyde ilişki olduğu sonucuna ulaşmışlardır. Bilgin (2021) yapmış olduğu çalışmada öğrencilerin 
BT'den yararlanma seviyelerini belirlemeyi amaçlamıştır ve araştırma sonucunda öğrencilerin BT'den yararlanma seviyelerinin farklı değişkenlere göre değişiklik gösterdiği gözlemlenmiştir.

Alanyazında yapılmış olan çalışmalar incelendiğinde öğrencilerin; okul dışı bilgisayar deneyimleri ve bilgisayar öğrenmeye yönelik öz-yeterlikleri ve değer inançları arasındaki ilişkilerini, BTY dersinde öğrendiklerini diğer derslerde kullanma becerilerini, BTY dersi kapsamındaki kavram yanılgılarını, robotik kodlama dersi hakkındaki görüşlerini, BTY dersi ile akademik başarıları arasındaki ilişkiyi, internet bağımlılıklarını ve BT'den yararlanma seviyelerini inceleyen çalışmalara rastlanırken ortaokul öğrencilerin BTY dersine yönelik özyeterlilikleri ile BTY dersine ilişkin görüşlerini birlikte ele alan herhangi bir çalışmaya rastlanılmamıştır. Öğrencilerin bir derse ilişkin görüşlerinin olumlu yönde ise o dersin kazanımlarına ilişkin öz-yeterlik düzeylerinin de yüksek olduğu düşünülmektedir ve öğrencilerin BTY dersine ilişkin öz-yeterlilikleri ile BTY dersine ilişkin görüşlerinin ele alınmasının alana katkı sağlayacağına inanılmaktadır.

\section{Yöntem}

\section{Araștırmanın Modeli}

$\mathrm{Bu}$ araştırmada karma araştırma yöntemi desenlerinden paralel karma yöntem deseni kullanılmıştır. Nitel ve nicel verilerin eş zamanlı olarak toplandığı paralel karma yöntem deseninde nitel ve nicel veriler eşit öneme sahiptir. (Creswell, 2008). Yapılan araştırmada nitel ve nicel veriler eş zamanlı olarak toplanmıştır ve veriler eşit derecede öneme sahiptir.

\section{Araştırma Alanı ve Katılımcılar}

Araştırmanın evreni Balıkesir ilindeki ortaokullarda öğrenimine devam eden beşinci sınıf ve altıncı sınıf öğrencilerinden oluşmaktadır. Araştırmanın örneklemini uygun örnekleme yöntemi ile seçilen 2020-2021 eğitim öğretim yılında Balıkesir ilindeki ortaokullarda öğrenimine devam eden 200 beşinci ve altıncı sınıf öğrencisi oluşturmaktadır. Örneklemi oluşturan 200 öğrenciden hem öz-yeterlik verileri hem de görüş verileri toplanmıştır. Uygun örnekleme yöntemi Büyüköztürk ve diğerleri (2016) tarafından araştırmacının kolaylıkla ulaşabildiği örneklemden veri toplaması olarak tanımlanmaktadır. Öğrencilerin demografik özelliklerinden cinsiyet ve sınıf düzeyine ilişkin dağılımları Tablo 1'de verilmiştir. 


\begin{tabular}{|c|c|c|c|c|}
\hline Cinsiyet / Sinıf & 5. Sinif & 6. Sinıf & $\begin{array}{c}\text { Toplam Öğrenci } \\
\text { Sayıs1 }\end{array}$ & $\%$ \\
\hline Kız & 48 & 47 & 95 & 47,5 \\
\hline Erkek & 60 & 45 & 105 & 52,5 \\
\hline Toplam & 108 & 92 & 200 & 100 \\
\hline
\end{tabular}

Tablo 1 incelendiğinde katılımcıların \%52,5'i erkek öğrencilerden oluşmaktadır. Araştırmaya katılan 200 öğrencinin \%54'ünün beşinci sınıf öğrencisi olduğu görülmektedir.

\section{Tablo 2}

Öğrencilerin Anne ve Babalarının Ĕ̆itim Düzeyi Dă̆ılımları

\begin{tabular}{|c|c|c|c|}
\hline \multirow{4}{*}{ Anne Eğitim Düzeyi } & Değişken & f & $\%$ \\
\cline { 2 - 4 } & Lise & 66 & 33 \\
\cline { 2 - 4 } & Ilkokul & 58 & 29 \\
\cline { 2 - 4 } & Ortaokul & 41 & 20,5 \\
\cline { 2 - 4 } & Üniversite & 35 & 17,5 \\
\cline { 2 - 4 } & Lisansüstü & 0 & 0 \\
\hline \multirow{4}{*}{ Baba Eğitim Düzeyi } & Lise & 80 & 40 \\
\cline { 2 - 4 } & Üniversite & 46 & 23 \\
\cline { 2 - 4 } & Ortaokul & 41 & 14 \\
\cline { 2 - 4 } & İlkokul & 28 & 2,5 \\
\cline { 2 - 4 } & Lisansüstü & 5 & 100 \\
\hline \multicolumn{2}{|c|}{ Toplam } & 200 & \\
\hline \multicolumn{2}{|c|}{} & & \\
\hline
\end{tabular}

Tablo 2'de yer alan verilerde öğrencilerin anne eğitim düzeylerinin; \%33’ünün lise, \%29'unun ilkokul, \%20,5'inin ortaokul, \%17,5'inin lisans eğitim düzeyinde olduğu görülürken lisansüstü eğitim düzeyinde anne veli profiline rastlanılmamıştır. Öğrencilerin baba eğitim düzeyleri incelendiğinde ise; \%40'ının lise, \%23'ünün üniversite, \%20,5'inin ortaokul, \%14'ünün ilkokul ve \%2,5'inin lisansüstü eğitim düzeyinde olduğu görülmüştür.

\begin{tabular}{|c|c|c|c|}
\hline \multicolumn{4}{|l|}{$\begin{array}{l}\text { Tablo } 3 \\
\text { Öğrencilerin Bilgisayar ve Internet Erişim Durumlarl }\end{array}$} \\
\hline \multirow{3}{*}{ Bilgisayara Sahip Olma } & Değişken & $\mathrm{f}$ & $\%$ \\
\cline { 2 - 4 } & Evet & 122 & 61 \\
\cline { 2 - 4 } & Hayır & 78 & 39 \\
\hline \multirow{2}{*}{ İnternet Erişimi } & Evet & 168 & 84 \\
\cline { 2 - 4 } & Hayır & 32 & 16 \\
\hline \multicolumn{2}{|c|}{ Toplam } & 200 & 100 \\
\hline
\end{tabular}


Tablo 3'te yer alan veriler incelendiğinde öğrencilerin \%61'inin ( $\mathrm{N}=122)$ bilgisayara sahip olduğu \%39'unun ( $N=78)$ bilgisayara sahip olmadığg; öğrencilerin \%84'ünün $(\mathrm{N}=168)$ internet erişimine olduğu görülürken \%16'sının $(\mathrm{N}=32)$ internet erişimine sahip olmadığ görülmüştür.

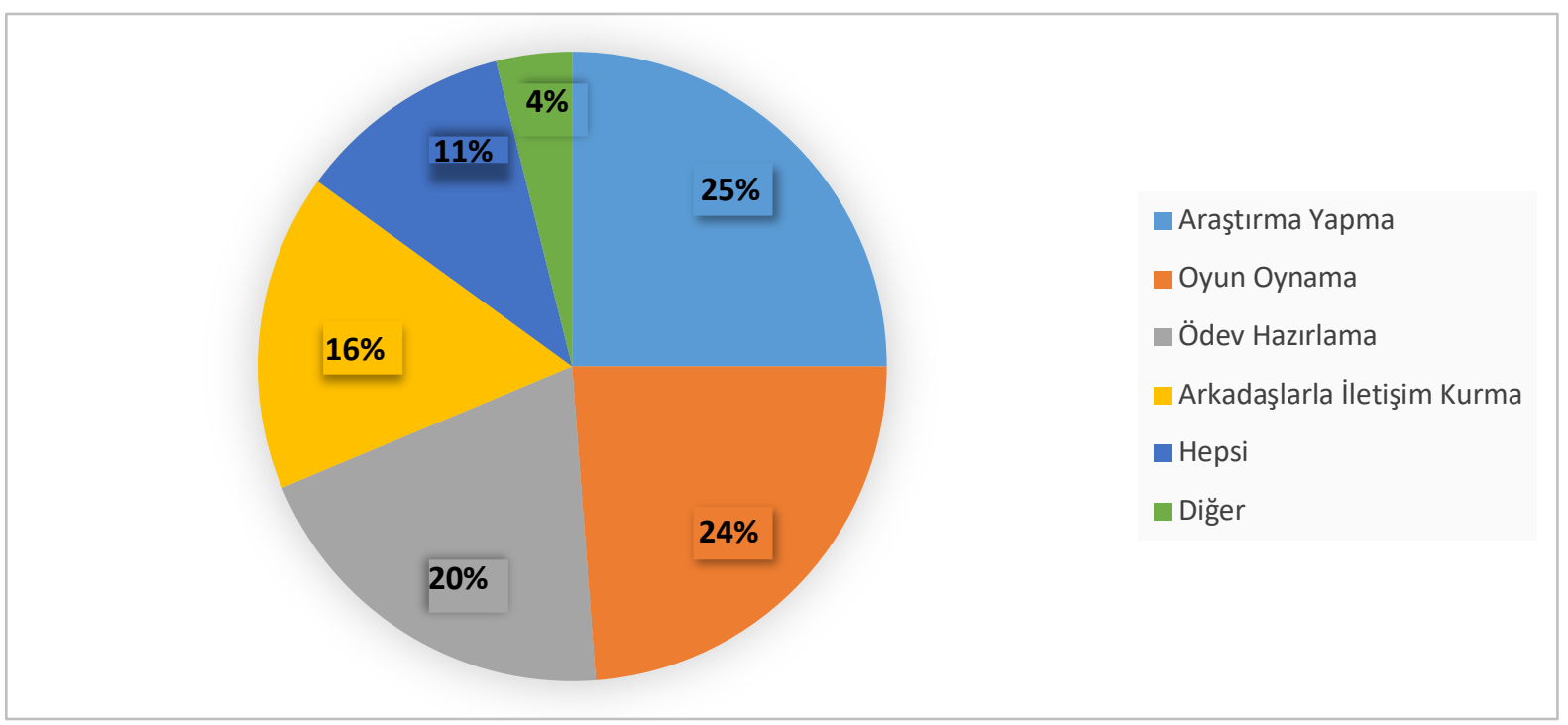

Grafik 1. Öğrencilerin Bilgisayar ve İnternet Kullanım Amaç Dağılımları

Öğrencinin bilgisayar ve internet kullanım amaçlarını belirlemek amacıyla öğrencilere “Araştırma Yapma”, “Oyun Oynama”, “Ödev Hazırlama”, “Arkadaşlarla İletişim Kurma” gibi seçenekler verilmiştir ve öğrenciler birden fazla seçim yapabilmektedir. Grafik 1'de yer alan veriler incelendiğinde öğrencilerin \%25'i (N=83) bilgisayar ve interneti araştırma yapmak için kullandığını, \%24'ü (N=79) oyun oynamak için kullandığını, \%20'si (N=66) ödev hazırlamak için kullandığını, \%16'sı (N=54) arkadaşları ile iletişim kurmak için kullandığını, \%11'i $(\mathrm{N}=37)$ hepsi için kullandığını belirtirken \%4'ü $(\mathrm{N}=13)$ ise film/video izlemek vb. aktiviteler için kullandıklarını belirtmişlerdir.

\section{Veri Toplama Araçları}

Araştırmada öğrencilerin BTY dersine ilişkin öz-yeterlikleri belirlemek amacıyla “Ortaokul Öğrencileri İçin Bilişim Teknolojileri Öz-Yeterlik Algısı Ölçeği” [OÖBTÖA] kullanılmıştır. Göçer ve Türkoğlu (2018) tarafindan geliştirilen OÖBTÖA ölçeği toplam 30 maddeden oluşan 5'li likert tipinde bir ölçektir. Ölçekte, "Bana hiç uymuyor" (1), "Bana çok 
az uyuyor" (2), "Bana uyuyor" (3), "Bana oldukça uyuyor" (4) ve "Bana tamamen uyuyor" (5) olmak üzere beş seçenek yer almaktadır. Ölçekten alınabilecek puanlar 30 ile 150 puan arasında değişmektedir. Ölçeğin Cronbach Alpha iç tutarlılık katsayısı 0,90 olarak hesaplanmıştır ve Alpar'a (2020) göre Cronbach Alpha değerinin 0,80 ile 1,00 arasında değer alıyor olması geliştirilen ölçeğin yüksek güvenirliğe sahip olduğunu gösterir.

Öğrencilerin BTY dersine ilişkin görüşlerini belirlemek amacıyla araştırmacı tarafından "Bilişim Teknolojileri ve Yazılım Dersi Görüş Formu” [BTYG] hazırlanmıştır. Görüşme tekniği, araştırma konusu ile ilgili araştırmacının derinlemesine bilgi elde etmesine olanak sağlar. Araştırmacı ile katılımcılar arasında güven sağlanması ile karmaşık konuların ifade edilmesine olanak sağlaması görüşme tekniğinin avantajlarından biridir (Büyüköztürk ve diğerleri, 2016). Araştırma planlanırken hazırlanan yarı yapılandırılmış görüşme formu, veri toplama sürecinde eğitimin uzaktan eğitim olarak devam etmesi nedeniyle yazılı görüş alma formu olarak kullanılmıştır. Araştırma soruları ele alınarak hazırlanan form 10 açık uçlu sorudan oluşmaktadır. Hazırlanan yarı yapılandırılmış görüşme formunda yer alan 8 soru öğrencilerin BTY dersine ilişkin görüşleri ile ilgili iken 2 soru ise öğrencilerin Covid-19 süreci ile ilgili görüşleri ile ilgilidir. Hazırlanan anket için ölçek geliştirme konusunda deneyimli ve Bilgisayar ve Öğretim Teknolojileri Eğitimi anabilim dalında görev yapmakta olan 2 öğretim üyesinden uzman görüşün alınmıştır. Uzmanlardan alınan geri dönütlere göre sorularda gerekli düzenlemeler yapılmıştır ve uzmanlar tarafından kontrol edilip onaylanmıştır. Öğrencilerin Covid-19 pandemisi sürecinde eğitime uzaktan eğitim olarak devam etmesi üzerine bu süreçte yaşadıkları olumlu/olumsuz durumlara ilişskin görüşleri de incelenmiştir. BTYG ile öğrencilerden BTY dersinin faydaları, BTY ders konularının zorluk dereceleri, Covid-19 pandemi döneminde öğrencilerin yaşadıkları olumlu ve olumsuz durumlar ile ilgili görüşleri alınmıştır.

\section{Veri Toplama Süreci}

2020-2021 eğitim öğretim yılında Covid-19 pandemi sürecinde okullarda eğitimin uzaktan eğitim olarak devam etmesi üzerine araştırma verileri Balıkesir ilinde öğrenimine devam etmekte olan ortaokul öğrencilerinden Google Forms aracılığı ile toplanmıştır. Öğrenciler formda yer alan ölçekleri gönüllü olarak cevaplandırmışlardır. Veriler 2021 yılının Haziran ayı içerisinde yaklaşık iki hafta süren bir süre içinde toplanmıştır. 


\section{Veri Analizi}

Araştırmada OÖBTÖA ölçeğinden elde edilen veriler istatistiksel analiz paket programı (IBM SPSS Statistics) kullanılarak analiz edilmiştir. Öğrencilerin BTY dersine ilişkin özyeterliklerine ilişkin puanlarının cinsiyet değişkenine, sınıf düzeyi değişkenine, kendine ait bilgisayara sahip olma değişkenine ve internete erişim değişkenine göre farklılaşıp farklılaşmadığını belirlemek için ilişkisiz örneklemler için T-testi kullanılmıştır. T-testi, iki ortalama arasındaki farkları test etmek için kullanılır (Büyüköztürk ve diğerleri, 2020). Öğrencilerin BTY dersine ilişkin öz-yeterliklerine ilişkin puanlarının anne ve baba eğitim düzeyine göre farklılaşmadığını belirlemek için ilişkisiz örneklemler ANOVA kullanılmıştır. ANOVA, iki ya da daha çok örneklem arasındaki ortalamaların anlamlı farkını test etmek için kullanılır (Büyüköztürk, 2020). Araştırmada BTYG formundan elde edilen veriler düzenlenerek yorumlanmıştır.

\section{Etik Konular}

Araştırma Balıkesir Üniversitesi ve Balıkesir İl Milli Eğitim Müdürlüğg̈ tarafından 21.05.2021 tarihinde onaylanmıştır. Araştırmada veriler tamamen gönüllülük esasına dayanarak toplanmıştır. Öğrencilere ulaştırılan formun başında araştırmanın kapsamı, amacı ifade edilmiştir. Aynı zamanda öğrencilerin verdikleri bilgilerin araştırma amacı dışında herhangi bir amaçla kullanılmayacağı belirtilmiştir.

\section{Bulgular ve Yorumlar}

Araştırmanın birinci problemi "Öğrencilerin BTY dersine ilişkin öz-yeterlikleri ne düzeydedir?" sorusu ile ilgili bulgular Tablo 4'te verilmiştir.

Tablo 4

Öğrencilerin BTY Dersine İlişkin Öz-Yeterliklerine Yönelik Veriler

\begin{tabular}{|c|c|c|c|c|c|c|c|c|c|}
\hline \multirow{2}{*}{ Ö̈BТÖA } & $\mathrm{N}$ & Ranj & Min & Max & Ortalama & Medyan & $\begin{array}{c}\text { Standart } \\
\text { Sapma }\end{array}$ & Skewness & Kurtosis \\
\cline { 2 - 10 } & 200 & 119 & 31 & 150 & 105,96 & 109 & 28,19 &,- 474 &,- 290 \\
\hline
\end{tabular}

Tablo 4 verilerine göre öğrencilerin (N=200) OÖBTÖA ölçeğinden aldıkları ortalama puan 105,96'dır. Öğrencilerin ortalama puanları olan 105,96 beş üzerinden değerlendirildiğinde 3,53 puan yapmaktadır. Elde edilen puanlara göre öğrencilerin BTY özyeterliklerinin orta seviyede olduğu görülmektedir. Araştırmada öğrencilerin verilerinin 
normal dağılım gösterip göstermediği için Skewness ve Kurtosis değerlerine bakılmıştır. Elde edilen veriler için Kurtosis değerinin -,290, Skewness değerinin ise -,474 olduğu görüşmüştür. Skewness ve Kurtosis değerlerinin $-1,5$ ile $+1,5$ arasında değer alması normal dağılım gösterdiğini ifade etmektedir (Tabachnick ve Fidell, 2013).

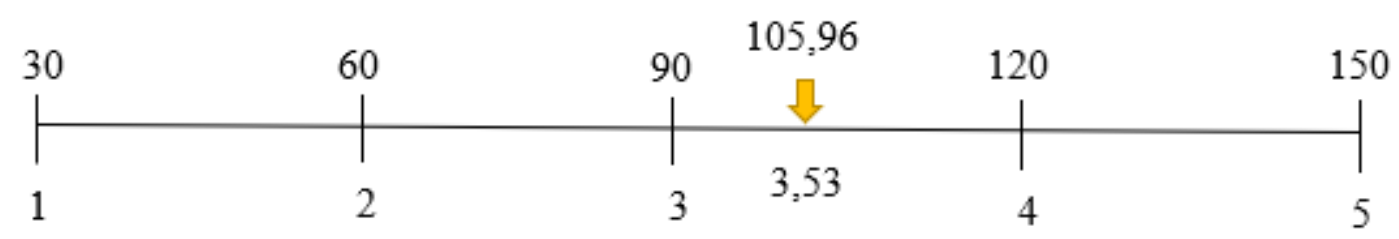

Grafik 2. Öz-Yeterlik Toplam Puanlarının Ortalaması

Ortaokul öğrencilerinin BTY dersine ilişkin öz-yeterliklerinin bazı değişkenlere (cinsiyet, sınıf düzeyi, anne eğitim düzeyi, baba eğitim düzeyi, bilgisayara sahip olma ve internet erişim durumlarına) göre farklılaşıp farklılaşmadığı incelenmiş, bulgular sırasıyla sunulmuştur.

Ortaokul öğrencilerinin BTY dersine ilişkin öz-yeterliklerinin cinsiyet değişkenine göre anlamlı bir farklılık gösterip göstermediğini analiz etmek için t-testi yapılmıştır ve analiz sonuçları Tablo 5'te verilmiştir.

\section{Tablo 5}

BTY Öz-Yeterlik Ölçeği Puanlarının Cinsiyete Göre T-Testi Sonuçları

\begin{tabular}{|c|c|c|c|c|c|c|}
\hline Cinsiyet & $\mathrm{N}$ & $\overline{\mathrm{X}}$ & $\mathrm{S}$ & $\mathrm{sd}$ & $\mathrm{t}$ & $\mathrm{p}$ \\
\cline { 1 - 4 } Erkek & 105 & 106,22 & 28,38 & 198 & \multirow{2}{*}{, 136} &, 892 \\
\cline { 1 - 4 } $\mathrm{K} 1 \mathrm{z}$ & 95 & 105,67 & 28,11 & & & \\
\hline
\end{tabular}

Tablo 5 incelendiğinde öğrencilerin BTY dersine yönelik öz-yeterlikleri cinsiyete göre anlamlı bir farklılık göstermemektedir, $\mathrm{t}(198)=, 136, \mathrm{p}=, 89>0,05$. Öğrencilerin BTY dersine yönelik öz-yeterlik ortalamaları incelendiğinde erkek öğrencilerin ortalamalarının $(\bar{X}=106,22)$ kız öğrencilerin ortalamalarından $(\bar{X}=105,67)$ yüksek olduğu ancak anlamlı bir farklılık göstermediği görülmektedir.

Ortaokul öğrencilerinin BTY dersine ilişkin öz-yeterliklerinin sınıf düzeyi değişkenine göre anlamlı bir farklılık gösterip göstermediğini analiz etmek için t-testi yapılmıştır ve analiz sonuçları Tablo 6'da verilmiştir. 


\begin{tabular}{|c|c|c|c|c|c|c|}
\hline \multicolumn{7}{|l|}{$\begin{array}{l}\text { Tablo } 6 \\
\text { BTY Öz-Yete }\end{array}$} \\
\hline Sınıf Düzeyi & $\mathrm{N}$ & $\bar{X}$ & $\mathrm{~S}$ & $\mathrm{sd}$ & $\mathrm{t}$ & $\mathrm{p}$ \\
\hline 5. Sinif & 108 & 104,47 & 26,42 & \multirow[t]{2}{*}{198} & \multirow{2}{*}{,808 } & \multirow{2}{*}{,420 } \\
\hline 6. Sinif & 92 & 107,71 & 30,18 & & & \\
\hline
\end{tabular}

Tablo 6 incelendiğinde öğrencilerin BTY dersine yönelik öz-yeterlikleri sınıf düzeylerine göre anlamlı bir farklılık göstermemektedir, $\mathrm{t}(198)=, 808, \mathrm{p}=, 42>0,05$. Öğrencilerin BTY dersine yönelik öz-yeterlik ortalamaları incelendiğinde altıncı sınıf öğrencilerinin ortalamalarının $(\bar{X}=107,71)$ beşinci sınıf öğrencilerinin ortalamalarından $(\bar{X}=104,47)$ yüksek olduğu ancak öğrencilerin BTY dersine yönelik öz-yeterliklerinin sinıf düzeylerine göre anlamlı bir farklılık göstermediği görülmektedir.

Ortaokul öğrencilerinin BTY dersine ilişkin öz-yeterliklerinin anne eğitim düzeyi değişkenine göre anlamlı bir farklılık gösterip göstermediğini analiz etmek için ANOVA yapılmıştır ve betimsel istatiksel analiz sonuçları ve anne eğitim düzeyine göre ANOVA sonuçları Tablo 7'de verilmiştir.

\begin{tabular}{|c|c|c|c|c|c|c|c|c|c|}
\hline \multicolumn{9}{|l|}{ Tablo 7} & $\begin{array}{l}\text { Öz-Yeterlik Ölçeği Puanlarının Betimsel İstatistikleri ve Anne Eğitim Düzeyine Göre } \\
\text { ANOVA Sonuçlarl }\end{array}$ \\
\hline $\begin{array}{c}\text { Anne Eğitim } \\
\text { Düzeyi }\end{array}$ & $\mathrm{N}$ & $\overline{\mathrm{X}}$ & SS & $\begin{array}{l}\text { Varyansin } \\
\text { Kaynağ1 }\end{array}$ & $\begin{array}{l}\text { Kareler } \\
\text { Toplam1 }\end{array}$ & sd & $\begin{array}{c}\text { Kareler } \\
\text { Ortalamas1 }\end{array}$ & $\mathrm{F}$ & $\mathrm{p}$ \\
\hline İlkokul & 58 & 104,03 & 29,46 & $\begin{array}{c}\text { Gruplar } \\
\text { arasi }\end{array}$ & 1061,366 & 3 & 353,789 & ,441 & ,724 \\
\hline Ortaokul & 41 & 103,63 & 28,15 & Gruplar içi & 157090,314 & 196 & 801,481 & & \\
\hline Lise & 66 & 106,98 & 28,68 & Toplam & 158151,680 & 199 & & & \\
\hline Üniversite & 35 & 109,94 & 25,67 & & & & & & \\
\hline Toplam & 200 & 105,96 & 28,19 & & & & & & \\
\hline
\end{tabular}

Tablo 7 incelendiğinde öğrencilerin BTY dersine yönelik öz-yeterlikleri anne eğitim düzeyine göre anlamlı bir farklılık göstermemektedir, $F(3,196)=, 441, p=, 72>0,05$. Anne eğitim düzeyleri arasında farkların hangi gruplar arasında olduğunu bulmak amacıyla yapılan Scheffe testinin sonuçlarına göre anne eğitim düzeyi Üniversite eğitim düzeyinde olan öğrencilerin $(\overline{\mathrm{X}}=109,94)$ BTY öz-yeterlik düzeyleri anne eğitim düzeyi ilkokul $(\overline{\mathrm{X}}=104,03)$, ortaokul $(\overline{\mathrm{X}}=103,63)$ ve lise $(\overline{\mathrm{X}}=106,98)$ olan öğrencilerden daha yüksektir.

Ortaokul öğrencilerinin BTY dersine ilişkin öz-yeterliklerinin baba eğitim düzeyi değişkenine göre anlamlı bir farklılık gösterip göstermediğini analiz etmek için ANOVA 
yapılmıştır ve betimsel istatiksel analiz sonuçları ve baba eğitim düzeyine göre ANOVA sonuçları Tablo 8'de verilmiştir.

\begin{tabular}{|c|c|c|c|c|c|c|c|c|c|}
\hline $\begin{array}{l}\text { Tablo } 8 \\
\ddot{O ̈}_{z-Y e t e r l i k} \text { Öl } \\
\text { ANOVA Sonuç }\end{array}$ & $\begin{array}{l}\breve{g} i P_{l} \\
r l\end{array}$ & nlarını & Betin & sel İstatisti & eri ve Bab & $E \breve{g} t$ & m Düzeyin & Göre & \\
\hline $\begin{array}{l}\text { Baba Eğitim } \\
\text { Düzeyi }\end{array}$ & $\mathrm{N}$ & $\overline{\mathrm{X}}$ & SS & $\begin{array}{c}\text { Varyansıın } \\
\text { Kaynağ } 1\end{array}$ & $\begin{array}{l}\text { Kareler } \\
\text { Toplamı }\end{array}$ & $\mathrm{sd}$ & $\begin{array}{c}\text { Kareler } \\
\text { Ortalamas1 }\end{array}$ & F & $\mathrm{p}$ \\
\hline İlkokul & 28 & 96,32 & 31,15 & $\begin{array}{c}\text { Gruplar } \\
\text { aras1 }\end{array}$ & 10002,803 & 3 & 3334,268 & 4,41 &, 005 \\
\hline Ortaokul & 41 & 113,27 & 22,53 & Gruplar içi & 148148,878 & 196 & 755,862 & & \\
\hline Lise & 80 & 100,70 & 30,89 & Toplam & 158151,680 & 199 & & & \\
\hline $\begin{array}{c}\text { Üniversite ve } \\
\text { Lisansüstü }\end{array}$ & 51 & 113,63 & 22,89 & & & & & & \\
\hline Toplam & 200 & 105,96 & 28,19 & & & & & & \\
\hline
\end{tabular}

Tablo 8 incelendiğinde öğrencilerin BTY dersine yönelik öz-yeterlikleri baba eğitim düzeyine göre anlamlı bir farkl1lık göstermektedir, $\mathrm{F}(3,196)=4,41, \mathrm{p}=, 005=0,05$. Bu anlamlı farklılık baba eğitim düzeyi Üniversite ve Lisansüstü olan öğrencilerin BTY dersine yönelik öz-yeterliklerinin $(\bar{X}=113,63)$ baba eğitim düzeyi İlkokul olan öğrencilerin BTY dersine yönelik öz-yeterliklerinden $(\overline{\mathrm{X}}=96,32)$ daha yüksek olmasından kaynaklanmaktadır. Baba eğitim düzeyleri arasında farkların hangi gruplar arasında olduğunu bulmak amacıyla yapılan Scheffe testinin sonuçlarına göre baba eğitim düzeyi Üniversite- Lisansüstü eğitim düzeyinde olan öğrencilerin $(\overline{\mathrm{X}}=113,63)$ ve baba eğitim düzeyi Ortaokul düzeyinde olan öğrencilerin $(\overline{\mathrm{X}}=113,27)$ BTY öz-yeterlik düzeyleri, baba eğitim düzeyi Lise düzeyinde olan öğrencilerin $(\bar{X}=100,70)$ ve baba eğitim düzeyi İlkokul olan öğrencilerin $(\bar{X}=96,32)$ BTY öz-yeterlik düzeylerinden yüksektir.

Ortaokul öğrencilerinin BTY dersine ilişkin öz-yeterliklerinin bilgisayara sahip olma değişkenine göre anlamlı bir farklılık gösterip göstermediğini analiz etmek için T-testi yapılmıştır ve analiz sonuçları Tablo 9'da verilmiştir.

\begin{tabular}{|c|c|c|c|c|c|c|}
\hline \multicolumn{7}{|c|}{$\begin{array}{l}\text { BTY Öz-Yeterlik Ölçeği Puanlarının Bilgisayara Sahip Olma Durumuna Göre T-Testi } \\
\text { Sonuçları }\end{array}$} \\
\hline $\begin{array}{c}\text { Bilgisayara Sahip } \\
\text { Olma }\end{array}$ & $\mathrm{N}$ & $\overline{\mathrm{X}}$ & $\mathrm{S}$ & sd & $\mathrm{t}$ & $\mathrm{p}$ \\
\hline Evet & 122 & 110,55 & 27,64 & \multirow[t]{2}{*}{198} & \multirow[t]{2}{*}{2,93} & \multirow[t]{2}{*}{,004 } \\
\hline Hayır & 78 & 98,78 & 27,70 & & & \\
\hline
\end{tabular}


Tablo 9'da yer alan veriler incelendiğinde öğrencilerin BTY dersine yönelik özyeterlikleri bilgisayara sahip olma durumuna göre anlamlı bir farklılık göstermektedir, $\mathrm{t}(198)=2,93, \mathrm{p}=, 004<0,05$. Öğrencilerin BTY dersine yönelik öz-yeterlik ortalamaları incelendiğinde bilgisayara sahip olan öğrencilerin ortalamalarının $(\overline{\mathrm{X}}=110,55)$ bilgisayara sahip olmayan öğrencilerin ortalamalarından $(\bar{X}=98,78)$ yüksek olduğu ve öğrencilerin BTY dersine yönelik öz-yeterliklerinin bilgisayara sahip olma durumlarına göre anlamlı bir farklılık gösterdiği görülmektedir.

Ortaokul öğrencilerinin BTY dersine ilişkin öz-yeterliklerinin internet erişimine sahip olma değişkenine göre anlamlı bir farklılık gösterip göstermediğini analiz etmek için T-testi yapılmıştır ve analiz sonuçları Tablo 10'da verilmiştir.

Tablo 10

BTY Öz-yeterlik Ölçeği Puanlarının Internet Erişimine Sahip Olma Durumuna Göre TTesti Sonuçları

\begin{tabular}{|c|c|c|c|c|c|c|}
\hline $\begin{array}{c}\text { İternet Erişimine } \\
\text { Sahip Olma }\end{array}$ & $\mathrm{N}$ & $\overline{\mathrm{X}}$ & $\mathrm{S}$ & $\mathrm{sd}$ & $\mathrm{t}$ & $\mathrm{p}$ \\
\hline Evet & 168 & 105,69 & 28,56 & 198 & \multirow{2}{*}{, 309} &, 758 \\
\hline Hayır & 32 & 107,38 & 26,50 & & & \\
\hline
\end{tabular}

Tablo 10 incelendiğinde öğrencilerin BTY dersine yönelik öz-yeterlikleri internet erişim durumlarına göre anlamlı bir farklılık göstermemektedir, $t(198)=, 309, \quad p=, 78>0,05$. Öğrencilerin BTY dersine yönelik öz-yeterlik ortalamaları incelendiğinde internet erişimine sahip olmayan öğrencilerin ortalamalarının $(\bar{X}=107,38)$ internet erişimine sahip olan öğrencilerin ortalamalarından $(\bar{X}=105,69)$ yüksek olduğu ancak anlamlı bir farklılık göstermediği görülmektedir.

Araştırmanın ikinci problemi olan "Öğrencilerin BTY dersine yönelik görüşleri nelerdir?” sorusuna için öğrencilerin BTY dersine yönelik görüşlerini belirlemek amacıyla hazırlanan BTYG formunda öğrencilere; BTY dersinde en eğlenceli buldukları konular, en zorlandıkları konular, BTY dersinde yer alan konuları günlük hayatta kullanımları ve Covid19 pandemisinin hayatımıza girmesi ile yaşadıkları olumlu/olumsuz durumların yer aldığı 10 soru sorulmuştur. Katılımcıların gizliliği gereği öğrenciler “Ö” olarak kodlanmış ve öğrencilere “Ö1, Ö2, Ö3,...” olmak üzere sıra numaraları verilmiştir. Araştırmaya katılan 200 öğrencinin 11'i görüşme formunda yer alan sorulara nitelikli cevap vermediği için 189 öğrencinin yanıtları incelenmiştir. Araştırmada öğrencilerden elde edilen veriler düzenlenerek gruplandırılmış ve yorumlanmıştır. 
Öğrencilerin BTY dersini faydalı bulup bulmadıklarını belirlemek amacıyla sorulan soruya, Ö54: “Evet düşünüyorum. Benim kodlamaya ilgim var, HTML, CSS, JS gibi konulara merakım var kodlama konusunun benim için faydalı olduğunu düşünüyorum. ” ve Ö191: “Evet faydalı bir ders olduğunu düşünüyorum. Office programlarının (Excel, PowerPoint, Word) benim için faydalı olduğunu düşünüyorum." yanıtlarını verirken Ö165 ise "Pek faydalı olduğunu düşünmüyorum” yanıtını vermiştir. Öğrencilerin verdikleri yanıtlar incelendiğinde öğrencilerin tamamına yakınının (N=179) BTY dersini faydalı bulduğu, öğrencilerin kodlama $(\mathrm{N}=32)$, Office programları $(\mathrm{N}=11)$ ve algoritma $(\mathrm{N}=10)$ konularını daha faydalı buldukları görülmüştür.

Öğrencilerin BTY dersi içinde yer alan konulardan hangilerini daha fazla sevdiklerini belirlemek amacıyla sorulan soruya; Ö55: "Kodlamayı işlemek bana daha çok eğlenceli geldi. 1- Kodlama 2- Excel İşlem 3- Programlarl Öğrenme PowerPoint vb." ve Ö157: “Bilişim teknolojileri dersini çok sevdim çünkü bilgisayar sistemleri ve elektronik belgelerin uzantılarını ögrendim ve Excel ve PowerPoint gibi uygulamaları ögrendik." yanıtlarını verirken Ö57 ise "Hayır sevmedim. Çünkü bilişim teknolojileri bana göre çok akıcı geçmiyor diğer dersler gibi." yanıtını vermiştir. Öğrencilerin verdikleri yanıtlar incelendiğinde öğrencilerin tamamına yakını (N=173) BTY dersinin konularını sevdiklerini ve BTY dersini işlerken eğlendiklerini belirtmişlerdir. Öğrencilerin en çok sevdiği konular incelendiğinde öğrencilerin Office programları $(\mathrm{N}=37)$, Scratch $(\mathrm{N}=46)$, algoritma $(\mathrm{N}=14)$ konularını daha çok sevdikleri görülmüştür.

Öğrencilerin BTY dersi içinde yer alan konulardan hangilerinde zorlandıklarını belirlemek amacıyla sorulan soruya; Ö28: “Sadece yazılım konusunda zorlanıyorum. ” ve Ö62 : "Çok zorlandığım bir konu olmadı ama kodlamadaki hataları ayıklamakta biraz zorlandım onun dışında yok." yanıtlarını verirken Ö34 ise "Hiçbir konuda zorlanmadım ögrretmenlerim sayesinde konuları güzelce anladım ve öğrendim." yanıtını vermiştir. Öğrencilerin verdikleri yanıtlar incelendiğinde öğrencilerin çoğunluğu (N=108) BTY dersinde zorlandıklarını belirtmiştir. Öğrencilerin en çok zorlandığı konular incelendiğinde öğrencilerin Scratch’te $(\mathrm{N}=31)$, Word $(\mathrm{N}=8)$ ve Excel'de $(\mathrm{N}=12)$ zorlandıkları görülmüştür.

Öğrencilerin blok tabanlı programlama kendilerini nasıl bulduklarını ve ders dışında blok tabanlı kodlama etkinlikleri yapıp yapmadıklarını belirlemek amacıyla sorulan soruya; Ö95: "Yetenekli olduğumu düşünüyorum. Ders dışında Scratch etkinliği yapıyorum. Animasyon yapıyorum." ve Ö129: "Yetenekli olduğumu düşünüyorum ders dışında yardım alarak araba yarışı oyunu geliştirdim. ” yanıtlarını verirken Ö150: “Pek yetenekli olduğumu düşünmüyorum fakat, derslerde işledikçe daha başarılı olacağımı düşünüyorum.” ve Ö155: “Hayır, 
bilgisayarım olmadığı için etkinlikleri uygulayamıyorum." yanıtlarını vermişlerdir. Öğrencilerin verdikleri yanıtlar incelendiğinde öğrencilerin çoğunluğu $(\mathrm{N}=105)$ blok tabanlı programlamada kendini yetersiz bulmaktadır ve bu nedenle ders dişında blok tabanlı programlama etkinlikleri yapmadıklarını belirtmişlerdir.

Öğrencilerin BTY dersinde öğrendikleri bilgileri evde tekrar edip etmediklerini belirlemek amacıyla sorulan soruya; Ö23: "Tekrar yapıyorum en çok Paint ve algoritma konularını seviyorum.”, Ö33: "Evet pratiğe dayalı derslere evde çalışlyorum. Örneğin zamanım oldukça Scratch uygulamasında etkinlikler yapıyorum.” ve Ö95: “Evet, derste ögrendiğim bilgileri evde tekrar ediyorum. En çok sunu programları konusuna çalışmayı seviyorum.” yanıtlarını verirken Ö58: “Hayır, çünkü ben bilişim teknolojileri ve yazılım dersini pek fazla sevmiyorum. ” ve Ö103: “Fazla tekrar etmiyorum çünkü derste hemen konuyu anında anlayabildiğini düşünüyorum." yanıtlarını vermişlerdir. Öğrencilerin verdikleri yanıtlar incelendiğinde öğrencilerin çoğunluğu $(\mathrm{N}=112)$ BTY ders konularını ders dışında da tekrar ettiğini belirtmişlerdir.

Öğrencilerin BTY dersinde öğrendikleri konulardan günlük hayatta en çok hangilerini kullandıklarını belirlemek amacıyla sorulan soruya; Ö36: "Hepsini kullanıyorum. Ama en çok işime yarayan kelime işlemci programlar." yanıtını verirken Ö133: "En çok Paint gibi uygulamaların kullanışlarını ögrenmiştik. En çok bu uygulamaları kullanıyorum.” yanıtını vermiştir.

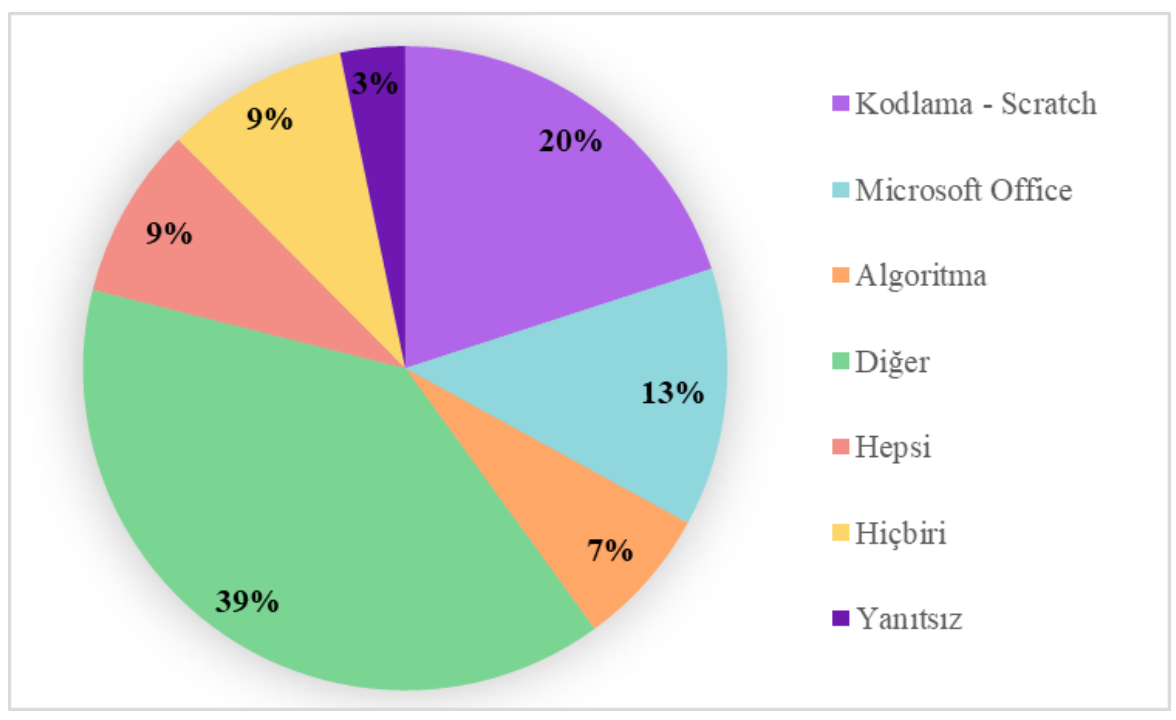

Grafik 3. Öğrencilerin BTY Konularından En Çok Kullandıkları Bilgiler

Öğrencilerin verdikleri yanıtlar incelendiğinde öğrencilerin \%20'si Scratch, Code.org gibi blok temelli programlama etkinliklerinden öğrendiklerini uyguladıklarını belirtirken 
\%13'ü Microsoft Office programlarından öğrendiklerini uyguladıklarını belirtmişlerdir. Öğrencilerin \%39’u siber güvenlik, Paint ve dosya işlemleri gibi konularında öğrendiklerini uyguladıklarını belirtirken, öğrencilerin \%9’u tüm öğrendiklerini uyguladıklarını belirtmişlerdir. Öğrencilerin \%9’u ise BTY dersi konularından öğrendikleri bilgileri uygulamadıklarını belirtmişlerdir.

Öğrencilerin BTY dersinde öğrendiklerini uygularken yardım alıp almadıklarını belirlemek amacıyla sorulan soruya; Ö24: "Yardım almadan yapamıyorum en çok ablam yardımcı oluyor.”, Ö58: "Evet alıyorum. Sınıfta bir arkadaşım çok iyi biliyor bilişim teknolojileri ve yazllım dersini ondan yardım alıyorum ve derste ögrretmeninden yardım alıyorum.”, Ö62: “Uygulayabiliyorum ama çok zorlanırsam babamdan yardım alıyorum.” ve Ö149: “Yardım almadan uygulaya biliyorum." yanıtlarını vermişlerdir. Öğrencilerin yarısına yakını (N=81) BTY dersinde öğrendiklerini yardım almadan uygulayamadığını belirtmişlerdir.

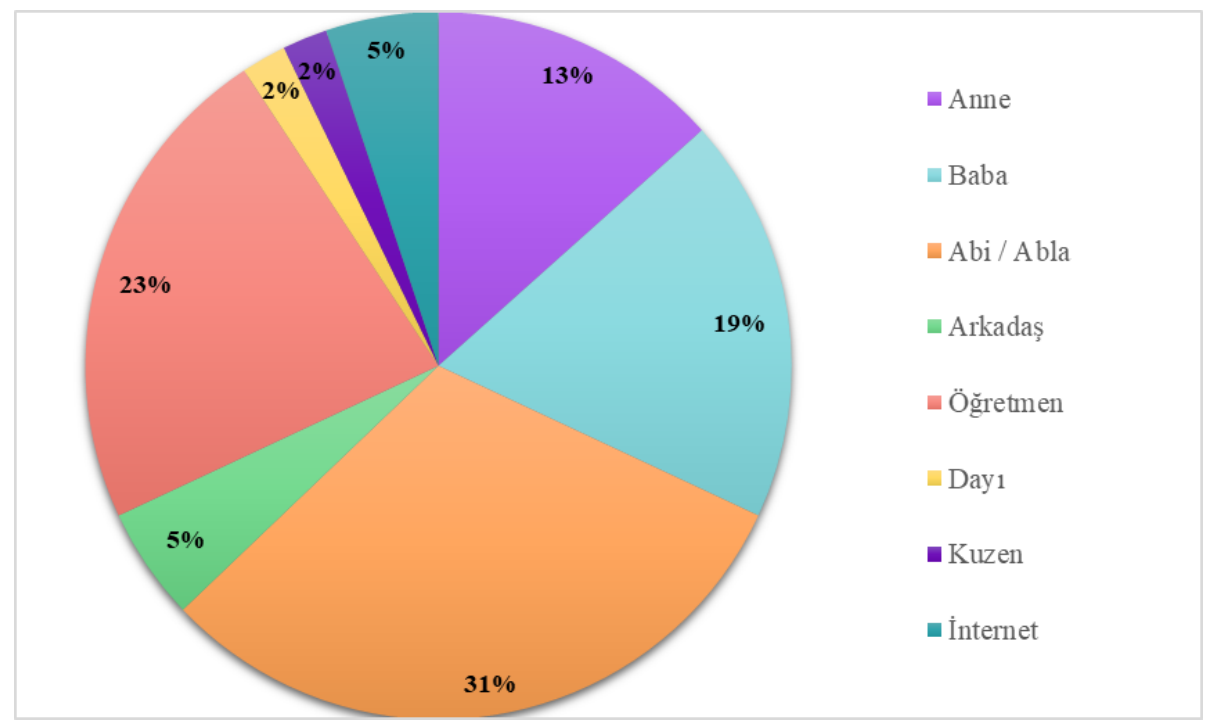

Grafik 4. Öğrencilerin Yardım Aldıkları Kişiler

BTY dersinde öğrendiklerini yardım almadan uygulayamadığını belirten 81 öğrencinin yardım aldıkları kişiler incelendiğinde öğrencilerin \%31'i abisi ya da ablasından yardım aldığını belirtirken, \%23'ü öğretmeninden, \%19'u babasından, \%13'ü ise annesinden yardım aldığını belirtmiştir.

Öğrencilerin BTY dersinde öğrendikleri konuların günlük hayatta hangi konularda yararlı olabileceği hakkındaki düşüncelerini belirlemek amacıyla sorulan soruya; Ö33: "Algoritmayı bir problemi çözmeye çalışırken kullanabilirim, Word gibi programları ögrendiğim için ileride kolayca bir ödevimi ya da araştırmamı yapabilirim.”, Ö53: “ileride 
bilgisayar kullanmam gerektiğinde rahatça kullanabileceğim, Bilgisayar üzerinden bir görüşme yapacağım zaman kimseden yardım almam gerekmeyecek ve istediğim zaman kodlama kullanarak bir program geliştirebileceğim.”, Ö54: “Büyüyünce yazılımcı olmak istiyorum yardım edeceğini düşünüyorum. İşlem yapmanın yardım edeceğini düşünüyorum. Algoritmanın yardım edeceğini düşünüyorum. ", Ö72: “Bilgisayar mühendisi olursam kodlama içime yarayabilir ya da bir program veya oyun yaparsam yine kodlama işime yarayacaktır.", Ö150: "Eğger ileride teknolojik aletlerle ilgili bir meslek sahibi olursam benim için çok yararlı olacağını düşünüyorum.”, Ö160: “Bilişim güvenliğimi, hayalimdeki meslek için kodlama yapmamı ve sunum hazırlamama yardımcı olacă̆ını düşünüyorum.”, Ö191: “Öğretmenlerim ödev verdiği zaman slayt olarak sunabilirim, Excel programıyla verilen görevleri yerine getirebilirim (hesap yapabilirim), Word belgesiyle notlar çıkartıp yazdırabilirim." ve Ö196: "Gelecekteki mesleğim de işime yarayabilir bilgisayarda bir işlem yapacă̆ım zaman yararlı olabilir ve ödev yaparken yararlı olabilir." yanıtlarını verirken Ö165 ise “Pek yararlı olacağını düşünmüyorum. ” yanıtını vermiştir.

Araştırmanın son problemi olan "Öğrencilerin Covid-19 pandemisi sürecinde yaşadıkları olumlu ve olumsuz durumlar nelerdir?" sorusu ile ilgili bulgular şu şekildedir:

Öğrencilerin Covid-19 pandemisi sürecinde yaşadıkları olumlu durumları belirlemek amacıyla sorulan soruya; Ö4: "Sabahları uyanıp giyinmeme ardından okula gitmeme gerek kalmıyor, Bazen çok acıktı̆̆ı̆da derste bir şeyler atıştırabiliyorum, Öğretmenin yazın dediği şeyleri ekran görüntüsü alıp sonradan yazabiliyorum.”, Ö35: “Özel ders yapar gibi tek başıma işliyormuş gibi hissediyorum. Anlamadiğım konuları daha iyi anllyorum.", Ö94: “Ailem ile daha fazla vakit geçirmek ve dinlenmek.", Ö105: "Derslerimizden geri kalmadık, konuları gayet iyi anladık, okulun önemli olduğunu anladık." ve Ö151: "Evde daha çok vakit geçirdim ve evde daha çok ders çalıştım. Evde çok etkinlikler yaptım." yanıtlarını verirlerken Ö17: “Hiçbir olumlu yanı yok." ve Ö54; “Bence çok olumlu bir yanı olmadı fakat söylemem gerekirse İngilizce dersi güzel geçti. Bilgisayar dersini bilgisayardan işlemek beni mutlu etti. Bu kadar aklıma geliyor.” yanıtlarını vermişlerdir.

Öğrencilerin Covid-19 pandemisi sürecinde yaşadıkları olumsuz durumları belirlemek amacıyla sorulan soruya; Ö4: “Çok çabuk dikkatim dağıllyor, bazı etkinlikleri yapamıyoruz ve iletişim kurması zorlaşıyor.”, Ö11: “Bazen derse giremedim, arkadaşlarımızla görüşmedik, dışarıya çıkamadık.”, Ö22: “Bazen soru çözen birinin veya öğretmenin sesi gelmeyebiliyor bu yüzden dersimiz kötü geçiyor. Bazen internet gidip geliyor bizi dersten atıyor veya derse bağlanamıyoruz.” ve Ö35: “Arkadaşlarımla görüşemiyorum. Öğretmenlerimi gerçekte hiç 
göremedim hep online olarak işledik. Ses veya kamera sıkıntısı ve İnternet sorunları yaşayabiliyorum." yanıtlarını verirken Ö1: “Negatif bir yanı yok.” ve Ö33: “Çok olumsuz bir durum ile karşılaşmadım fakat bazen elektrik, internet kesintisi gibi durumlar yaşadı̆̆ım için derslere katılamadım fakat eksiklerimi ögretmenim sayesinde kolayca tamamladım." yanıtlarını vermişlerdir.

\section{Sonuçlar}

Teknolojinin her geçen gün hayatımızda önem kazanması ile teknoloji eğitimi önem arz etmeye başlamıştır ve Türkiye'de beşinci sınıftan itibaren BTY dersi zorunlu olarak verilmeye başlanmıştır (Göçer ve Türkoğlu, 2018). Bu araştırmanın amacı BTY dersi alan ortaokul öğrencilerinin BTY dersine ilişkin öz-yeterliklerini ve görüşlerini belirlemektir. Öğrencilerin BTY dersine ilişkin öz-yeterlikleri incelendiğinde; öğrencilerin öz-yeterliklerinin baba eğitim düzeyine ve kendine ait bilgisayara sahip olma durumuna göre anlamlı farklılık gösterdiği sonuçlarına ulaşılmıştır. Baba eğitim düzeyi üniversite-lisansüstü olan öğrencilerin özyeterliklerinin baba eğitim düzeyi ilkokul düzeyinde olan öğrencilerin öz-yeterlik düzeylerinden yüksek olduğu, kendine ait bilgisayara sahip olan öğrencilerin öz-yeterliklerinin bilgisayara sahip olmayan öğrencilerin öz-yeterlik düzeylerinden yüksek olduğu sonuçlarına ulaşılmıştır. Öğrencilerin kendilerine ait bilgisayarlarının olması öğrencilere derste yapılan çeşitli etkinlikleri tekrar etme imkanı sunmaktadır. Öğrencilerin derste yapılan etkinlikleri tekrar etmeleri derse ilişkin öz-yeterliklerinin artmasında yardımcı olduğu düşünülmektedir. Aynı zamanda öğrencilerin BTY dersine ilişkin öz-yeterliklerinin öğrencilerin cinsiyet, sınıf düzeyi, anne eğitim düzeyi ve internet erişimine sahip olma değişkenlerine göre anlamlı bir farklılık göstermediği sonuçlarına ulaşılmıştır. Araştırmada elde edilen sonucun aksine Solmaz'ın (2015) yapmış olduğu çalı̧̧mada öğrencilerin BTY dersine ilişkin yeterliklerinin cinsiyet ve anne-baba eğitim düzeyine göre farklılaştı̆ı görülmüştür. Solmaz (2015) yapmış olduğu çalışmada kız öğrencilerin BTY dersine ilişkin yeterliklerinin erkek öğrencilerin yeterliklerinden yüksek seviyede olduğu, öğrencilerin anne ve babalarının eğitim düzeyi azaldıkça öğrencilerin BTY ders yeterliklerinin azaldığı sonuçlarına ulaşmıştır.

Araştırma bulgularına göre öğrencilerin BTY dersine yönelik görüşleri incelendiğinde öğrencilerin görüşlerinin olumlu yönde olduğu görülmüş̧ür. Araştırmada elde edilen bu sonucun aksine BTY dersine ilişkin görüşleri incelenen öğrencilerin tamamına yakını BTY dersinin BTY dersinin faydalı bir ders olduğunu düşünmektedir ve öğrenciler BTY ders konularını sevdiklerini, BTY dersi işlenirken eğlendiklerini belirtmişlerdir. BTY dersinin 
uygulamalı bir ders olmasının öğrencilerin dersi eğlenceli bulmasına etkisi olduğu düşünülmektedir. Göksoy ve Yılmaz (2018) da yapmış oldukları çalışmada öğrencilerin robotik ve kodlama dersine yönelik görüşlerini incelemişlerdir ve araştırma sonucunda öğrencilerin robotik ve kodlama dersi işlenirken eğlendikleri sonucuna ulaşmışlardır. Öğrencilerin BTY dersinde zorlanma durumları incelendiğinde öğrencilerin çoğunluğunun BTY dersinde zorlandığı sonucuna ulaşılmıştır. Öğrencilerin en çok zorlandığı konular incelendiğinde ise Scratch'te belirli kod bloklarında, Word ve Excel'de zorlandıkları görülmüştür aynı zamanda öğrencilerin çoğunluğunun blok tabanlı programlamada kendini yetersiz bulduğu sonucuna ulaşılmıştır. Öğrencilerin BTY dersinde öğrendiklerini ders dışında tekrar etme durumları incelendiğinde öğrencilerin çoğunluğunun BTY ders konularını ders dışında da tekrar ettiğini sonucuna ulaşılmıştır. Öğrencilerin BTY konularından en çok kullandıkları bilgiler incelendiğinde öğrencilerin \%39'unun siber güvenlik, Paint ve dosya işlemlerinden öğrendiklerini ders dışında da uyguladıkları sonucuna ulaşılırken \%20'inin ise blok temelli programlamada öğrendiklerini ders dışında uyguladıkları sonucuna ulaşılmıştır. Öğrencilerin BTY dersinde öğrendiklerini uygularken yardım alma durumları incelendiğinde ise öğrencilerin \%42,9'u yardım aldığını, \%42,9'u yardım almadığını ve \%11,6'sı bazen yardım aldığını ifade etmiştir. Öğrencilerin yardım aldıkları kişiler incelendiğinde ise öğrencilerin çoğunluğunun abisi ya da ablasından yardım aldığı sonucuna ulaşılmıştır. Öğrencilerinin en çok yardım aldıkları kişilerin abi ya da ablalarının olmasının nedeninin öğrencilerin abi-ablalarının da BTY dersi almış olabileceğinden kaynaklandığ düşünülmektedir. Araştırmada öğrencilerin bilgisayar kullanım amaçları incelenmiştir ve elde edilen bulgulara göre öğrencilerin çoğunluğunun bilgisayarı araştırma yapmak ve oyun oynamak için kullandığı sonucuna ulaşılmıştır. Bu sonuç Solmaz'ın (2015) yapmış olduğu çalışmanın sonucu ile benzerlik göstermektedir. Solmaz (2015) yapmış olduğu çalışmada öğrencilerin çoğunun bilgisayarı araştırma yapmak ve oyun oynamak için kullandığı sonucuna ulaşırken Vekiri ve Chronaki (2008) ise yapmış oldukları çalışmada da öğrencilerin bilgisayarı farklı amaçlar için kullandıkları sonucuna ve öğrencilerin en fazla bilgisayarı oyun oynamak için kullandıkları sonucuna ulaşmışlardır. Aynı zamanda araştırmada öğrencilerin Covid-19 pandemisi sürecinde yaşadıkları olumlu-olumsuz durumlar incelenmiştir ve öğrencilerin çoğunluğu evde aileleri ile zaman geçirmiş olmalarını ve derslerinden geri kalmamış olmalarını pandeminin olumlu yanları olarak değerlendirirken arkadaşları ile görüşememiş olmalarını ve canlı derslerde yaşanılan internet erişiminin kopması, ses sorunu gibi teknik sorunları pandeminin olumsuz yanları olarak değerlendirdikleri görülmüştür. 


\section{Öneriler}

Altıncı sınıf düzeyinde olan öğrencilerin BTY dersine ilişkin öz-yeterliklerinin beşinci sınıf düzeyinde yer alan öğrencilerin öz-yeterlik düzeylerine göre daha yüksek olduğu sonucuna ulaşılmıştır. Beşinci sınıf öğrencilerinin öz-yeterliklerinin neden düşük olduğu araştırılmalı ve çözümler üretilerek öz-yeterliklerinin arttırılması sağlanmalıdır.

Öğrencilerin verdikleri yanıtlar incelendiğinde kendine ait bilgisayarı olan öğrencilerin BTY ders öz-yeterliklerinin kendine ait bilgisayarı olmayan öğrencilere göre daha yüksek seviyede olduğu görülmüştür. Kendine ait bilgisayarı olmayan öğrencilerin BTY ders özyeterliklerini arttırmak için ders dişı etkinlikler gerçekleştirilebilir ve öğrencilerin bilgisayar ile daha fazla zaman geçirmesi sağlanabilir.

Öğrencilerin çoğu Word ve Excel programlarında zorlandığını belirttikleri görülmüştür. Öğrencilerin Word ve Excel programlarında kendilerini geliştirmeleri için diğer branş öğretmenleri ile iş birliği yapılarak çeşitli etkinlikler planlanabilir.

Öğrencilerin Scratch’te zorlandığını belirttikleri görülmüştür. Blok temelli kodlamada zorlanmadığını belirten öğrenciler ile zorlandığını belirten öğrencileri bir araya getirip gruplara ayırarak ögretmen rehberliğinde blok temelli kodlamada kendilerini geliştirmeleri için çeşitli etkinlikler planlanabilir.

Öğrencilerin çoğunun BTY dersinde zorlandığı özellikle de blok temelli programlama da kendilerini yetersiz hissettikleri görülmüştür. Öğrencilerin blok temelli programlamada kendilerini geliştirmeleri için çeşitli görevler verilebilir ve sınıf içi - okul içi çeşitli blok temelli programlama etkinlikleri planlanabilir. 


\section{Kaynakça}

Alpar, R. (2020). Spor, Sağllk ve Eğitim Bilimlerinden Örneklerle Uygulamalı İstatistik ve Geçerlik - Güvenirlik. Ankara: Detay Yayıncılık.

Bandura, A. (1997). Self-efficacy: The Exercise of Control.W. H. Freeman and Company.

Bilgin, Enes A. (2021) Ortaokul öğrencilerinin bilişim teknolojilerinden yararlanma düzeylerinin farklı değişkenler açısından incelenmesi. ISPEC International Journal of Social Sciences \& $\quad$ Humanities $\quad 5(2), \quad$ 178-188. https://doi.org/10.46291/ISPECIJSSHvol5iss2pp178-188

Büyüköztürk, Ş. (2020) Sosyal Bilimler Iç̧in Veri Analizi El Kitabı İstatistik, Araştırma Deseni, Spss Uygulamalarl ve Yorum. Ankara: Pegem Yayıncılık.

Büyüköztürk, Ş., Çokluk, Ö., ve Köklü, N. (2020) Sosyal Bilimler Iç̧in İstatistik. Ankara: Pegem Yayıncılık.

Büyüköztürk, Ş., Kılıç Çakmak, E., Akgün, Ö. E., Karadeniz, Ş., ve Demirel, F. (2016). Bilimsel Araştırma Yöntemleri. Ankara: Pegem Yayıncılık.

Creswell, J. W. (2008). Educational research planning, conducting and evaluating quantitative and qualitative research. International Pearson Merril Prentice Hall.

EDUCAUSE. (2021). 2021 EDUCAUSE Horizon Report Teaching and Learning Edition. EDUCAUSE. https://www.learntechlib.org/p/219489/

Eryılmaz, S., Sarıçayır, D., ve Yıldız, G. (2020). Öğrencilerin bilişim teknolojileri özyeterlik algısı ile internet bağımlılığının incelenmesi. Eğitim ve Toplum Araştırmaları Dergisi 7(2), 609-638. https://dergipark.org.tr/en/pub/etad/issue/58757/815166

Göçer, G., ve Türkoğlu, A. (2018). Ortaokul öğrencilerine yönelik bilişim teknolojileri özyeterlik algısı ölçeği: Geçerlik ve güvenirlik çalışması. Mehmet Akif Ersoy Üniversitesi Ĕ̈itim Fakültesi Dergisi, say1 46,223-238. DOI: 10.21764/ maeuefd.394086

Göksoy, S., ve Yılmaz, İ. (2018). Bilişim teknolojileri öğretmenleri ve öğrencilerinin robotik ve kodlama dersine ilişkin görüşleri. Düzce Üniversitesi Sosyal Bilimler Enstitüsü Dergisi, 8(1), 178-196. https://dergipark.org.tr/tr/pub/dusbed/issue/38695/449771

İnanç, Y. B., ve Yerlikaya, E. E. (2011). Kişilik Kuramları (6. Baskı). Ankara: Pegem Akademi. 
Mcmillan, J. H. (2000). Educational Research: Fundamentals for the Consumer ( $3^{\text {th }}$ Ed.). New York: Longman.

MEB. (2019). 5. Sinıflar Bilişim Teknolojileri ve Yazılım Dersi Öğretmen Rehberi. 1-5. http://tegm.meb.gov.tr/meb_iys_dosyalar/2017_10/03105825_OgretmenRehberi_compressed.pdf

Özgenel, M., Baydar, F., ve Çalışkan Yılmaz, F. (2018). Ortaokul öğrencilerinin bilişim teknolojileri ve yazılım dersine yönelik tutumları ile akademik başarıları arasındaki ilişkinin incelenmesi. Journal of Turkish Studies, 13(6), 111-128. https://doi.org/10.7827/turkishstudies.12962

Özkan, M. A., ve Şahin, H. (2019). 5. ve 6. sınıf bilişim teknolojileri dersinde öğrencilerin öğrenme stratejileri ile akademik başarılarının karşılaştırmalı olarak incelenmesi. Avrasya Uluslararası Araştırmalar $\quad$ Dergisi, $\quad 7(17), \quad$ 394-415. https://doi.org/10.33692/avrasyad.590710

Solmaz, S. (2015). Ortaokul öğrencilerinin bilişim teknolojileri ve yazılım dersinde öğrendikleri bilgileri diğer derslerde kullanabilme becerileri (Yayımlanmamış Yüksek Lisans Tezi). Yeditepe Üniversitesi, İstanbul.

Tabachnick, B. G. And Fidell, L. S. (2013). Using multivariate statistics. Boston, Pearson.

Ulaş-Karaahmetoğlu, G. (2020). Ortaokul öğrencilerinin bilgisayar kullanımı ve internet bağımlılığı düzeylerinin incelenmesi. ERÜ Sağllk Bilimleri Fakültesi Dergisi; 7(2): 1-9. https://dergipark.org.tr/tr/pub/erusaglik/issue/59791/798438

Usta, E., Arslankara, V. B., ve Özarslan, M. (2016). Ortaokul öğrencilerinin bilişim teknolojileri ve yazılım dersine ilişkin kavram yanılgılarının incelenmesi. Gazi Eğitim Bilimleri Dergisi, 2(1), 31-50. https://dergipark.org.tr/tr/download/article-file/419763

Vekiri, I., ve Chronaki, A. (2008). Gender issues in technology use: perceived social support, computer self-efficacy and value beliefs, and computer use beyond school. Computers \& Education, 51(3), 1392-1404. https://doi.org/10.1016/j.compedu.2008.01.003

Zimmerman, B. J. (1995). Self-efficacy and educational development. in a. Bandura (ed.). Selfefficacy in changing socities. New York: Cambridge University Press (pp. 202 -231). 


\section{Yazarlar Hakkında}

\section{Özge ÖZTUZCU}

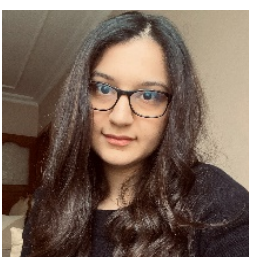

Lisans eğitimini Balıkesir Üniversitesi Necatibey Eğitim Fakültesi Bilgisayar ve Öğretim Teknolojileri anabilim dalında 2019 yılında tamamlamıştır. Bir yıl özel kurumda öğretmenlik deneyiminin ardından 2020 yılında Balıkesir Üniversitesi Fen Bilimleri Enstitüsü Bilgisayar ve Öğretim Teknolojileri anabilim dalında yüksek lisans eğitimine başlamıştır ve yüksek lisans eğitimine devam etmektedir.

Eposta: $\quad$ oztuzcuo@gmail.com

URL: $\quad$ https://orcid.org/0000-0003-2836-073X

\section{Dr. Öğr. Üyesi Ayşen KARAMETE}

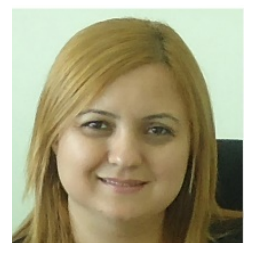

Lisans eğitimini, Uludağ Üniversitesi Necatibey Eğitim Fakültesi Matematik Öğretmenliği, yüksek lisans ve doktora eğitimlerini Balıkesir Üniversitesi Fen Bilimleri Enstitüsü Matematik Eğitimi Programında tamamlamıştır. Necatibey Eğitim Fakültesi Matematik Eğitimi ve Bilgisayar ve Öğretim Teknolojileri Eğitimi [BÖTE] Bölümlerinde Araştırma Görevlisi olarak görev yapmıştır. Halen Bilgisayar ve Öğretim Teknolojileri Eğitimi bölümünde öğretim üyesi olarak görev yapmaktadır.

Eposta: $\quad$ karamete@balikesir.edu.tr

URL: $\quad$ https://orcid.org/0000-0001-8442-2080 